\title{
PENERIMAAN MASYARAKAT TEHADAP PERILAKU KAWIN LARI (STUDY KASUS KELURAHAN MALAKAJI KECAMATAN TOMPOBULU KABUPATEN GOWA)
}

\author{
Murni $^{1}$, Asis Muslimin ${ }^{2}$, Suardi $^{3}$ \\ ${ }^{1}$ Pendidikan Sosiologi, Universitas Muhammadiyah Makassar \\ Email: murni@gmail.ac.id \\ ${ }^{2}$ Pendidikan Sosiologi, Universitas Muhammadiyah Makassar \\ Email: asismuslimin@unismuh.ac.id \\ ${ }^{3}$ Pendidikan Sosiologi, Universitas Muhammadiyah Makassar \\ Email: risfaisal@unismuh.ac.id
}

\begin{abstract}
The purpose of this study was to analyze people's acceptance of elopement behavior and of to analyze the community's understanding of elopement behavior. The study was a descriptive qualitative study, the research sample used purposive sampling with 7 informans. Data colletion techniques that are carried out by researchers are observation, interview and documentation. Data analysis method used is descriptive method. Research results prove that based on observation and results of research that has been done. The process of elopement. Is always subject to adat sanctions, after being subject to adat sanctions, the perpetrators of elopement must finish asking for permission from the family, especially parents and providing panai money. Society responses about elopement behavior are things that are despicable and detrimental to parens because it involves self-esteem and family good name.
\end{abstract}

Keywords: Eloping and Society

Abstrak. Tujuan penelitian ini adalah untuk menganalisis penerimaan masyrakat terhadap perilaku kawin lari dan untuk menganalisis pemahaman masyarakat terhadap perilaku kawin lari. Penelitian yang dilakukan merupakan penelitian kualitatif deskriptif. Sampel penelitian mengunakan purposive sampling dengan 7 informan.Teknik pengumpulan data yang lakukan oleh peneliti adalah Observasi, wawancara dan dokumentasi. Metode analisis data yang di gunakan yaitu metode deskriptif. Hasil penelitian membuktikan bahwa Berdasarkan pengamatan yang telah di teliti yaitu. Proses kawin lari selalu dikenakan sanksi adat, setelah dikenakan sanksi adat proses penerimaan kawin lari ini sudah meminta izin kepada kedua orang tua dan menyediakan uang panai. Tanggapan masyarakat tentang kawin lari yaitu suatu hal yang tercela dan merugikan orangtua karena ini menyangkut tentang harga diri dan nama baik keluarga.

Kata Kunci : Kawin Lari dan Masyarakat

\section{PENDAHULUAN}

Pernikahan merupakan suatu akad untuk menghalalkan hubungan antara laki-laki dan perempuan sebagai suami istri kedua belah pihak, dengan dasar suka rela dan keridhahan kedua belah pihak untuk mewujudkan suatu kebahgiaan dalam berumah tangga yang diliputi rasa kasih sayang dan ketentraman dengan cara-cara yang di ridhai Allah. Zaman globalisasi sekarang semakin marak terjadi kebebasan para generasi muda dalam bergaul antar pasangan yang cenderung bebas 
dalam hubungan percintaan ataupun asmara. Jika di tinjau dari dari segi pergaulanya sudah banyak yang menyimpang.

Penyebab terjadinya kawin lari silariang tidak adanya restu dari orang tua, karena adanya fitnah dari orang, hamil diluar nikah, faktor ekonomi, faktor usia. Dampak yang di timbulkan silariang di kelurahan malakaji kec. Tompobulu kab. Gowa adalah sering terjadi pertengkaran rumah tangga, adanya kebencian laki-laki dengan keluarga perempuan, pemutusan hubungan darah terhadap anak yang melakukan kawin lari, orangtua merasa sedih , kecewa dan sakit hati, tidak mendapatkan izin untuk menikah dari orang tua, orang yang melakukan kawin lari biasanya tidak baik. Awalnya keluarga mempelai laki-laki datang melamar dengan baik kepada keluarga mempelai perempuan akan tetapi lamaran sering di tolak karena keluarga mempelai laki-laki tidak sederajat dengan keluarga mempelai perempuan. Karena keluarga mempelai lakii-laki merasa ni paka siri' (dipermalukan) oleh pihak mempelai perempuan, maka untuk menegakkan siri' keluarganya maka laki-laki ini membawa perempuan pergi jauh dari kediamanya, biasanya kedua belah pihak sudah sepakat melakukan kawin lari.

Faktor yang melatarbelakangi kawin lari yaitu faktor suka sama suka, syarat-syarat pembiayaan terlalu tinggi atau terkendala di uang panai', laki-laki dan perempuan telah melakukan perlakuan yang bertentangan dengan hukum islam dan hkum adat dan yang terakhir faktor budaya atau tradisi adat. Tradisi kawin lari mengakibatkan adanya keharusan si gadis untuk tinggal serumah bersama si bujang sebelum terjadinya akad nikah. Cara penyelesaian kawin lari sama seperti pernikahan biasa hanya saja tidak lagi menggunakan pemilihan jodoh pertunangan tetapi langsung pada proses lamaran.

Walaupun kedua pasangan ini menyadari bahwa tindakan kawin larii (Silariang) ini penuh resiko tetapi itulah jalan terbaik baginya untuk membina rumah tangga dengan kekasihnya kelak. Kawin lari ini adalah suatu bentuk perkawinan yang tidak di benarkan oleh adat makassar terutama di gowa.khususnya di kelurahan malakaji itulah sebabnya para pelaku kawin lari disebut angyyala artinya orang yang menyalahi aturan adat dan aturan norma.

Dalam kehidupan sosial masyarakat Gowa dan suku makassar pada dasarnya kawin lari tersebut tidak dibenarkan, karena didalamnya ada hal-hal yang di langgar yaitu tidak mengindahkan asas usus musyawarah dan mufakat, terjadinya pemaksaan kehendak dan terbukanya aib keluarga maupun masyarakat karena kawin lari akan berpeluan terjadinya maksiat, penegakan hukum dan sanksi adat secara tegas dan adanya perasaan malu masyarakat terhadap perbuatan yang menyimpang ini sangat besar pengaruhnya dalam mengatur dalam mengatur kehidupan sosial dalam masyarakat. Setiap pelanggaran adat dalam kasus silariang atau kawin lari selalu mendapatkan sanksi berupa bahan pergunjingan terkadang di dalam kehidupang masyarakat, peristiwa kawin lari dilakukan kerabat akan menjadi bahan percekcokan dengan masyarakat sekitarnya yang berujung pada saling bunuh. Pertengakaran ini merupakan bentuk gejala awal yang melahirkan kebencian dan permusuhan dikalangan masyarakat.

Umumnya kawin lari dalam masyarakat suku makassar khususnya di masyarakat gowa dianggap sebagai penyelesaian hubungan rasa cinta yang mengalami hambatan dari pihak orang tua kerabat, karena masih ada sebagian masyarakat yang menetukan pilihan pasangan terhadap anakanaknya, mengakibatkan anak-anak maka kurang kebebasan dalam memilih pasangan hidup yang dikehendakinya, walaupun sudah ada juga orang tua yang membebaskan anaknya untuk memilih jodoh sendiri.

Pihak laki-laki biasanya membawa pergi perempuan ke rumah pak imam nanti kalau sudah dinikahi baru dibawa pergi kerumah laki-laki. Kedua belah pihak bisa menikah apabila dapat izin dari keluarga mempelai perempuan, dalam hal ini imam setempat yang memberikan persuratan kepada imam dimana tempat tinggal m,empelai perempuaan pelaku kawin lari karena biasanya apabila dilakukan persuratan izin terkadang tidak langsung di beri izin dari pihak keluarga mempelai perempuan dan ada juga tanpa sepengetahuan pihak keluarga mereka langsung menikah. Setelah beberapa bulan atau tahun lamanya di pelariang maka ada hasrat untuk Abbaji atau datang baik, maka pihak pemudapun mendatangi orang tua perempuan itu untuk menyampaikan maksudnya 
Abbaji, saat pihak laki-laki minta acara Abbaji, biasanya orang tua perempuan masih emosi, maka ia mewakilkan pada saudaranya untuk berembuk.

Bila terjadi kata sepakat untuk datang Abbaji, juga di tetapkan passala (uang denda). pelaku kawin lari bertahun-tahun baru datang baik atau a'baji ke keluarganya, terkadang sudah mempunyai anak baru datang baik, proses datang baik atau a'baji ini dilakukan apabila sudah meminta izin kepda kedua orangtua perempuan dan apabila sudah disetujui, maka selanjutnya dilakukan acara $a^{\prime}$ baji atau datang baik maka tidak ada lagi namanya tupakasiri' dan anyyala.

Proses datang baik adalah mengurus permintaan maaf boleh dilakukan oleh bersangkutan sendiri, melainkan harus melalui orang-orang tertentu yang memiliki wibawa atau tokoh masyarakat yang disegani Namun hal ini byukan merupakan jaminan untuk diterimanya kembali kekeluarganya, karena terkadang ada juga pemberian maaf sering di ulur-ulur oleh pihak keluarga perempuan, bahkan sampai bertahun tahun lamanya barulah bisa di beri maaf.

Memang konsekuensi kawin lari ini cukup berat bakah dihadapi, karena nyawa taruhanya selama mereka tidak datang a'baji atau datang baik. Terkadang orang yang melakukan kawin lari biasa ada yang tidak pulang baik walaupun telah menikah secara resmi di tempat dimana mereka melakukan kawin lari pasangan kedua belah pihak pasti ingin pulang baik ke orang tuanya akan tetapi pasangan kawin lari ini tidak diterima begitu saja oleh keluarga belah pihak.Agar bisa diterima oleh keluarga siperempuan dan menegakkan kembali siri' maka pelaku kawin lari ini harus menggelar acara atau berdamai dengan pihak keluarga si perempuan, pelaku kawin lari harus menyediakan sunrang atau bisa dikatakan mahar dan passala atau denda karena keduanya telah berbuat salah. Selain itu. Pihak laki-laki harus menyediakan uang panai'. Apabila pelaku silariang atau kawin lari belum bisa memenuhi semua itu maka keduanya tidak bisa pulang baik. Dan tinggal selamanya di tempat kawin lari.

Kasus pelaku kawin lari sebaiknya memang dihentikan setidaknya mengurangi terjadinya kawin lari karena dilihat dari dampak yang ditimbulkan oleh pelaku kawin lari lebih banyak menimbulkan mudarat daripada maslahat. Mungkin dsebagai solusinya, maka para tokoh adat dan tokoh agama, dan pendidik sebaiknya memberikan pencerahan kepada generasi muda agar tidak melakukan kawin lari, kemudian bagi orang tua yang memiliki anak gadis agar tidak membebani dengan permintaan sebagai maharnya. Sesungguhnya Allah SWT tidak suka orang yang berlebihan, dan dalam pemikiran dapat dilaksanakan dengan cara sederhana saja agar terhindar dari kawin lari, bagi siperempuan pun sebaiknya menyarankan kekasihnya untuk menempuh jalan peminangan saja dan tidak mudah diajak lari hanya karena alasan cinta.

\section{METODE PENELITIAN}

Jenis penelitian ini adalah kualitatif dengan metode analisis deskriptif yang bertujuan untuk mengetahuan penyebab terjadinya dan strategi penyelesaian konflik menantu yang tinggal serumah dengan mertua.Sampel penelitian mengunakan purposive sampling dengan 5 informan.Teknik pengumpulan data yang lakukan oleh peneliti adalah Observasi, wawancara dan dokumentasi. Kemudian dianalisis melalui reduksi data (data reduction), penyajian data (display data), penarikan kesimpulan (conclusion) dan menggunakan teknik keabsahan data.

\section{HASIL DAN PEMBAHASAN}

Sesuai dengan hasil penelitian yang menjelaskan tentang bagaimana proses penerimaan masyarakat terhadap perilaku kawin lari dan tanggapan masyarakat tentang kawin lari olehnya itu peneliti menginterpretasi di dalam pembahasan ini. Proses penerimaan masyarakat terhadap perilaku kawin lari dan tanggapan masyarakat tentang kawin lari memang selalu menjadi perbincangan dimasyarakat sekitar khususnya ibu-ibu yang suka dengan hal yang panas yang ada di masyarakat. 
Peneliti melakukan penelitian secara kualitatif deskriptif menggambarkan hal apa saja yang menjadi topik yang hangat di kelurahan malakaji kecamatan tompobulu kabupaten gowa melakukan pengkajian tentang penerimaan masyarakat terhadap perilaku kawin lari.

\section{a. Sanksi Adat}

Sanksi adat yang ada di kelurahan malakaji masih sangat kental karena menyangkut masalah harga diri dan nama baik dalam masyarakat dan keluarga, masyarakat di kelurahan malakaji sangat patuh terhadap aturan yang ada dan yang sudah diatur oleh tokoh agam dan masyarakat yang dianggap di percayai. Sanksi adat di kelurahan malakji emakin hari semakin meredup karena semakin canggihnya jaman sekarang dulu selalu ada kekerasan tapi dijaman sekarang sanksi adat yang berlaku tidak terlalu keras lagi bagi pelaku kawin lari.

\section{b. Proses Penerimaan Masyarakat Terhadap Perilaku Kawin Lari}

Masyarakat Kelurahan Malakaji menganggap pernikahan suatu hal yang sangat sakral dan yang sangat disukai ole Allah dan agama pernikahan merupakan sunnatullah yang berlaku untuk memperoleh kebahagiaan dab kesejahteraan lahir dan batin menuju kebahagiaan dab dunia dan akhirat. Perkawinan merupakan ibadah. Dan dan hal yang tidak disukai oleh masyarakat terkhusus oleh masyarakat kelurahan malakaji yaitu perilaku kawin lari. Proses penerimaan perilaku kawin lari harus dikenakan sanksi adat yang berlaku dikelurahan malakaji merupakan hal yang harus dipatuhi oleh orang yang melakukan kawin lari di kelurahan malakaji harus betul-betul mematuhi syaratsyarat dan ketentuan, penerimaan masyarakat kawin lari di kelurahan malakaji juga harus ada restu orang tua dan adanya ketentuan-ketentuan oleh pihak keluarga misalkan tentang uang panai' yang akan di bawah ke pihak perempuan setelah itu baru ditentukan bagaimana baiknya. Setelah semuanya selesai pihak keluarga dan masyarakat setempat dan kalau pelaku kawin lari yang tidak bisa memenuhi maka pihak dari laki-laki harus berbicara kembali kepada pihak perempuan agar bisa diterima oleh keluarga dan masyarakat. Proses datang baik adalah mengurus permintaan maaf boleh dilakukan oleh bersangkutan sendiri, melainkan harus melalui orang-orang tertentu yang memiliki wibawa atau tokoh masyarakat yang disegani.

Namun hal ini byukan merupakan jaminan untuk diterimanya kembali kekeluarganya, karena terkadang ada juga pemberian maaf sering di ulur-ulur oleh pihak keluarga perempuan, bahkan sampai bertahun tahun lamanya barulah bisa di beri maaf agar bisa diterima oleh keluarga siperempuan dan menegakkan kembali siri' maka pelaku kawin lari ini harus menggelar acara atau berdamai dengan pihak keluarga si perempuan, pelaku kawin lari harus menyediakan sunrang atau bisa dikatakan mahar dan passala atau denda karena keduanya telah berbuat salah. Selain itu. Pihak laki-laki harus menyediakan uang panai'. Apabila pelaku silariang atau kawin lari belum bisa memenuhi semua itu maka keduanya tidak bisa pulang baik. Dan tinggal selamanya di tempat kawin lari.

\section{c. Tanggapan Masyarakat Tentang Perilaku Kawin Lari}

Hasil pengamatan peneliti melihat Proses perkawinan orang makassar pada dasarnya dilakukan secara normatif sesuai ketentuan hukum agama maupun hukum adat yang mengatur prosesi perkawinan, misalnya kedua pihak yang akan menikah melakukan tahapan peminangan. Akan tetapi proses normatif perkawinan ini kadang dilanggar oleh warga karena beberapa alasan yang melatar belakanginya, baik karena hubungan mereka tidak direstui oleh orang tuanya atau keluarganya maupun karena penentuan uang panai' yang relatif mahal sehingga sebagian masyarakat menenpuh jalan pintas yang disebut dengan kawin lari perbuatan ini dianggap menyimpang atau bertentangan dengan hukum adat. Pada dasarnya kawin lari merupakan kehendak berdua laki-laki dan perempuan namun demikian persoalanya yaitu tetap menimbulkan siri'dari pihak kawin lari yang senantiasa mempunyai kewajiban menurut prosedur adat membunuhh orang 
yang salah perdamaian belum tercapai sebagai akibat larinya gadis bersama seorang pemuda pujaanya. Hal ini di pandang sebagai tantangan dan penghinaan terhadap kehormatan pihak keluarga perempuan tersebut, namun sebenrnya perginya seorang gadis bersama pria pujaanya atas dasar kehendk bersama tetapi pihak laki-laki tetaplah disalalahkan sehingga disebut sebagi pihak orang yang salah.Pihak pelaku kawin lari tetap pada pendirianya untuk memisahkan hubungan kedua pihak, beranggapan bahwa perbuatan kawin kari itu akan berdampak buruk pada nama baik orang tua atau merupakan aib bagi keluarga.

kawin lari merupakan perbutan yang menyimpang dan kawin lari merupakan perbuatan yang tidak di sukai oleh masyarakat karena merusak nama baik keluarga karena adat istiadat dikelurahan malakaji masih sangat kental dan di masyarakat malakaji ini sangat kental dengan adatnya, dan asnagat patuh dengan hukum adt yang berlaku disana, dan kawin lari adalah hal yang menyimpang karena orangtua stengah mati mencari nafkah untuk anak mereka akan tetatpi anaknya memperlakukan hal yang tercela dan kawin lari ini bisa merusak masa depan dan itu sangat memalukan untuk keluarga mereka dan mereka juga sanagat malu karena msih sekolah dan anaknya sudah melakukan hal yang tercela dan banyak orang tua yang merasa kesal terhadap anknya sendiri dan terlalu lama untuk memaafkan anak mereka karena ini adalah siri' bagi keluarga apalagi keluarga yang merupakan keturunan keluarga yang sangat di kenal di kelurahan tersebut otomatis keluarga merasa sudah di permalukan.

\section{d. Menentang Perjodohan}

Berdasarkan hasil pengamatan yang terjadi di kelurahan malakaji yaitu factor yang melatar belakangi terjadinya kawin lari yaitu salah satunya menetang perjodohan Menentang perjodohan (kawin paksa) kebiasaan sebagian orang tua, dalam mencarikan jodoh anknya selalu mencari dari luar keluarga dekat, baik itu sepupuh satu kali, dua kali dan tiga kali. Tujuanya agar harta warisan itu tidak jatuh keluar.

\section{e. Faktor Ekonomi}

Sesuai penagamatan yang peneliti lakukan yait factor yang selalu menyebabkan kawin lari yaitu factor ekonomi yang berlebihan kenapa karena jaman sekarang mereka melihat dari segi luaranya saja dan strata social yang tinggi atau kelas yang tinggi.

\section{f. Perilaku Yang Tidak Sesuai Dengan Harapan Orangtua}

perilaku yang tak sesuai harapan orang tua salah satu pihak teatapi menurut saya setiap orang tua menginginkan yang terbaik untuk anknya hidup bahagia kelak, untuk bahagia itu juga harus mencari calon suami dari yang baik-baik pula. Bilamana orang tua melihat kehidupan pemuda yang melamar anaknya tingkah lakunya buruk maka orang tua menolaknya. Faktor kelima: pergaulan bebabs, kalangan remaja jaman sekarang khususnya di kelurahan malakji selalu mencari hal-hal yang bersifat instan atau mereka hanya bertindak sesuai dengan naluri dalam dirinya tanp memikirkan dampak yang akan terjadi pada apa yang mereka lakukan. Pergaualan bebas yang dialakukan oleh remaja tdak terlepas dari pengaruh lingkungan, kurangnnya perhatian keluarga.

Dalam suku bugis makassar kawin lari sudah ada pada zaman dulu tapi zaman dulu sanksi adat yang berlaku di masyarakat sangat keras, karna ini masalh siri' yang sudah ada sejak dulu orang malakji sangat peka sekali sebab salah sedikit nyawa taruhanya, orang zaman dulu tidak mau harga dirinya di injak. Injak oleh orang lain, kapan ada anak gadisnya dilarikan maka bukan hanya bapaknya, juga keluarga perempuan mersa tersinggung karena siri'nya di injak-injak oleh pihak lakilaki yang mebawanya dan zaman dulu sanksi adat yang berlaku biasanya berakhir dengan maut. Tapi yang saya lihat zaman sekarang kurang peduli dengan kasus kawuin lari dan merasa bodoh kenapa karena yang saya lihat yang panting bisa mngurus semunya dan persyaratan hukum adat selesai mka semuanya bisa berjalan dengan lancar.itulah bedanya hukuk adat jaman sekarang dan jaman dulu tentang hukuman kepada pelaku kawin lari. 


\section{g. Tidak direstui oleh orangtua}

Dari pengamatan yang dilakukan oleh peneliti yaitu banyaknya tidak direstui oleh orang tuanya sehingga kaum pemuda pemudi yang ada di kelurahan malakaji itu sendiri banyak yang melakukan kawin lari karena orangtua mereka merasa tidak cocok atau tidak sebanding dengan pilihanya sendiri.

\section{h. Banyaknya Anak Yang Putus Sekolah}

Dari hasil pengamatan yang diteliti yaitu banyak remaja yang putus sekolah hanya karena mengejar nafsu semata karena cinta mereka kawin lari, mereka tidak memikirkan hal yang akan terjadi nantinya pada mereka yang melakukan kawin lari. Di kelurahan malakaji ini banyak anak-anak putus sekolah di karenakan mereka kawin lari dibawah umur ada yang kawin lari umur 14 dan ada yang kawin lari sejak umur 17 tahun, mereka melakukan ini semua dikarenakan tiadak adanya restu dari orang tua dan adanya perbedaan umur diantara pelaku kawin lari, dan sekarang mereka merasa menyesal karena melihat teman-temanya sudah menggapai cita-cinta mereka cuman bisa melihatnya adapun penyebab terjadinya kawin lari.

\section{i. Hamil Diluar Nikah}

Dari hasil pengamatan yang dilakukan peneliti yaitu banyaknya pemuda yang hamil diluar nikah karena mereka tidak tahu apa yang terjadi nanti karena ujungnya pasti mereka mempermalukan keluarga mereka sendiri, adapun penyebab terjadinya kawin lari yang miris di kelurahan malakaji ini yaitu hamil diluar nikah padahal perempuan ini masih sekolah di SMA dan mereka terpaksa kawin lari karena pihak laki-laki juga tidak bisa melamar pacarnya faktornya adalah uang panai' mahal dan faktor strata sosial dan pergaulan bebas maka mereka mengambil jalan pintas denagan melakukan kawin lari yang konsekuensinya sangat berat bagi mereka dan Harusnya orang tua sanagat berperan disini dikarenakan orang tua harus tegas dalam mendidik anak-anknya karena ini menyangkut masa depan si anak.

\section{j. Teknologi yang semakin meningkat}

Dari hasil pengamatan yang peneliti lihat yaitu perkembangan teknologi juga menjadi dampak negative dari perilaku kawin lari di kelurahan malakji tersebut, Perkembangan ilmu pengetahuan dan teknologi membawa dampak pada sistem perkawinan adat makssar baik kawin secara adat maupun kawin lari.kawin lari zaman dulu bertemu antara jejaka dan gadis sudah sangat sulit apalagi bergaul bebas seperti sekarang ini. Namun sekarang ini pergaulan muda mudi sangat jauh beda sekarang sudah banyak alat telekomunikasi yang super canggih yang bisa digunakan untuk berkomunikasi dengan kekasihnya, kapan dan dimanapun, mulai dari telepon, internet, HP hingga alat telekomunikasi lainya.

\section{k. Pergaulan Bebas}

Dari pengamatan peneliti yang dilihat yang sangat miris yaitu banyaknya remaja yang pergaulanya sangat bebas dalam memilih teman yang kurang baik Kasus seperti ini di kelurahan malakaji sudah banyak terjadi, apalagi pergaulan muda mudi sudah tidak dibatasi lagi cenderung bebas dlam bergaul, mereka sudah bisa saling berkunjung kerumah teman pria atau wanitanya atau bertemu di tempat yang sifatnya sangat rahasia, disanalah mereka kadang memadu cinta untuk merasakan apa arti nikmatnya cinta. 


\section{KESIMPULAN}

Berdasarakan hasil penelitian dan pembahasan tentang penerimaan masyarakat terhadap perilaku kawin lari dan tanggapan masyarakat tentang perilaku kawin lari dapat disimpulkan bahwa.

1. Penerimaan masayarakat terhadap perilaku kwin lari proses penerimaan masyarakat terhadap perilaku kawin lari dikelurahan malakaji biasanya dikenakan sanksi adat dan harus di kenakan sanksi adat setelah dikenakan sanksi adat. Proses penerimaan kawin lari ini sudah meminta izin kepada kedua orangtua menyediakan uang panai' dan menentukan hari baik mereka menggelar acara pesta sudah setujui oleh kedua orang tua mereka barulah mereka panggil pemerintah untuk memberitahukan kalau pelaku kawin lari sudah diterima dan melaksanakan aturan yang sudah berlaku. Dan sekarang sistem kekerasan oleh pihak pelaku kawin lari tidak lagi mengalami kekerasan oleh masyarakat dan keluarga karena semua telah dibicarakan dengan baik.

2. Tanggapan masyrakat tentang kawin lari yaitu orang yang memalukan orangtua atau orang yang tidak ada malunya dan orang yang menyimpang dan bertentangan dengan norma dan agama yang berlaku dalam masyarakat.

\section{DAFTAR PUSTAKA}

Baso, Munassir Beta, Ridwan Syam, Zainuddin Tika (2009), sejarah tompobulu, lembaga kajian dan penulisan sejarah budaya sulawesi selatan.

Creswell.(2012). pendekatan kualitatif, kuantitattif, Yogyakarta: putaka belajar.

Diah Eka Novia Susanti (2013), Tradisi Kawin Lari dalam Perkawinan Adat dan Kompilasi Hukum. Skripsi Stain Salatiga.

Khairunnisa,(2017) Dampak Praktek Kawin Lari Terhadap Kehidupan Keluarga Pada Masyrakat Kecematan Ketapang Kbupaten Gayo Lues. skipsi Uin Ar-Raniry Darussalam Band aceh

Natsir Said, Moh Mr,( Makassar 1962) Siri' dalam Hubungannya dengan Perkawinan di Masyarakat Mangkasara di Sulawesi Selatan, P,Sejahtera.

Nursalam, Suardi dan Syarufuddin. (2016).Teori Sosiologi Klasik, Modern, Posmodern, Saintifik, Hermeneutik, Kritis, Evaluatif, dan Integratif. Yogyakarta: writing revolution.

Puput Nurmarhama,(2018) Ekasistensi Perkawinan Silariang dalam Perspektif Hukum Adat di Desa Kapita Kecamatan Bangkala Kabupaten Jeneponto, jurnal.

Syukri Daeng Limpo, Moh. Drs,( 09 Desember 1984) Artikel masalah Kawin Lari, SKU Mimbar Karya.

Sinarti,(2017) Legalitas Wali Nikah Kawin Lari Perspektif Hukum Islam dan Kompilasi Hukum. Skripsi UIN Alauddin Makassar

Zainuddin Tika dan M. Ridwan Syam,(Juli 2004) Silariang:Pustaka Reflesi, Tulisan SKM Brakara weng Pos.

Zainuddin Tika,( Jakarta 1989) Siri dan Silariang, suatu tinjauan analisis kriminologi,

http://id.wikipedia.org/wiki/perilaku menyimpang

http://sosiologipedia.com./2017/01/teori-teori-penyimpangan-sosial.html?m=1

http://sihitamspeak-wprdpress-com.cdn.ampproject.org 